\title{
Öğretmenlerin Sınıf İçi Gündelik Deneyimleri: Fenomenolojik Bir Çalıșma
}

\author{
Abdullah SELViTOPU', Gülșen KÖROĞLU²
}

\begin{abstract}
Öz: Bu çalışmanın amacı öğretmenlerin sınıf içi gündelik deneyimlerini irdelemek ve söz konusu deneyimleri nasıl anlamlandırdıklarını ortaya çıkarmaktır. Bu amaç doğrultusunda öğrencilerle olan iletişim ve etkileşim, sınıf yönetimi süreçleri ve öğrenme ortamına ilişkin öğretmenlerin sınıf içi gündelik deneyimleri irdelenmiştir. Araştırmada nitel araştırma desenlerinden fenomonoloji deseni; verilerin toplanıp işlenmesi için yarı yapılandırılmış görüşme formu ve içerik analizi teknikleri kullanılmıştır. Çalışma grubu kamu okullarında görev yapan 5 öğretmenden oluşmaktadır. Çalışma grubunun belirlenmesi için amaçlı örnekleme yöntemi kullanılmıştır. Toplanan veriler içerik analizi ile analiz edilmiş; öğretmenlerin sınıf içi gündelik deneyimlerine ilişkin düşünceleri tespit edilmiştir. Yapılan analizler sonucunda öğretmenlerin sınıf içi gündelik deneyimlerinde, olumlu sınıf ikliminin oluşmasında öğrencilerle olan iletişim ve etkileşime önemli ölçüde vurgu yapmışlar ve sınıf içi otorite kurmanın sınıf yönetimiyle yakından ilgili olduğunu belirtmiş̧lerdir. Bunun yanı sıra katılımcılar, öğretmen öğrenci arasındaki mesafenin ilişkileri şekillendirici bir özelliğe sahip olduğunu ve istenmeyen öğrenci davranışlarına yönelik öğretmen müdahalesinin sınırlı düzeyde olduğunu vurgulamışlardır. Buna ek olarak, öğrenciyle kurulan sağlıklı iletişimin öğrencinin kendini ifade edebilme becerisini geliştirdiği, öğretmenlerle öğrenciler arasında oluşturulan mesafenin karşılıklı saygıyı oluşturduğu ve olumlu sınıf ikliminin ortaya çıkmasına katkı sağladığı söylenebilir.
\end{abstract}

Anahtar Sözcükler: Öğretmen, Sınıf içi gündelik deneyim, Fenomenoloji

\section{Teachers' Daily Experiences in the Classroom: A Phenomenological Study}

\begin{abstract}
The principal aim of the present study is to develop an in-depth understanding of teachers' everyday classroom experiences. To achieve this aim, the researchers seek to examine the interactions that occur between teachers and students in the classroom, the various classroom management processes put in place by teachers and the learning environment experiences of teachers. In this phenomenological study, semi-structured interviews are used to collect the required data. Moreover, the collected data are analysed by means of the content analysis technique. In accordance with the purposeful and typical sampling method, the study group comprises five public school teachers. The findings of the study reveal that the participants emphasised the role of positive interactions in relation to fostering a positive classroom climate. In addition, they considered that establishing classroom authority through the use of appropriate classroom management skills was very important. The participants also mentioned that social distance influences the relations between teachers and students, while teachers have only limited interventions available for tackling unwanted behaviours on the part of students. Furthermore, the participants suggested that good communication by teachers improves the communication skills of students, while the social distance between teachers and students helps to promote mutual respect and foster a positive classroom climate.
\end{abstract}

Keywords: Teacher, Daily experiences in classroom, Phenomenology

1 Karamanoğlu Mehmetbey Üniversitesi, Eğitim Fakültesi, Eğitim Bilimleri Bölümü, Karaman, Türkiye, e-posta: aselvi@kmu.edu.tr, ORCID: https://orcid.org/0000-0001-7045-468X

${ }^{2}$ Milli Eğitim Bakanlığı, Gevher Hatun Anaokulu, Karaman, Türkiye, e-posta: gulsen8080@hotmail.com.tr, ORCID: https://orcid.org/0000-0003-1507-1437 
Öğretmenlik mesleğinin tanımı, 1739 sayılı Milli Eğitim Temel Kanunu'nda, “Öğretmenlik, Devletin eğitim, öğretim ve bununla ilgili yönetim görevlerini üzerine alan özel bir ihtisas mesleğidir. Öğretmenler bu görevlerini Türk Milli Eğitiminin amaçlarına ve temel ilkelerine uygun olarak ifa etmekle yükümlüdürler. Öğretmenlik mesleğine hazırlık genel kültür, özel alan eğitimi ve pedagojik formasyon ile sağlanır (43. Madde)" ifadesi ile belirtilmektedir. Öğrencilerin öğrenmelerini kolaylaştırarak gelişimlerini destekleyen öğretmenlik yoğun bir eğitim almayı gerektiren profesyonel bir meslektir (Fumoto ve diğerleri., 2004). Ayrıca öğretmenlik eğitim sisteminin en önemli unsurlarından biridir. Eğitim sistemi ile kazandırılmak istenen amaçlar, öğretmenler aracılığıyla, örgün ve yaygın eğitim kurumlarında gerçekleştirilmektedir (Ergen, 2018).

Öğretmenlik, öğretmen öğrenci ilişkisinin ve etkileşimin önemli olduğu bir meslektir (Tofur, 2019; Yılmaz,2017). Bu çerçevede; etkileşim, iletişim ve ilişki kavramları üzerinde durmak önemlidir. Etkileşim, biyolojik, fiziksel, zihinsel, psikolojik ve sosyal olarak bireylerin birbirlerini etkilemesini ifade etmektedir (Dance, 1970). İletişim ise kişiler arasında anlamların ortak olması ve kişiler arası duygu ve düşüncelerin aktarım süreci olarak tanımlanmaktadır (Yüksel, 2019). İlişki, etkileşim ve iletişimin bir ürünüdür. İletişim olmadan etkileşim gerçekleşmemekte, dolayısıyla ilişki de ortaya çıkmamaktır (Tofur, 2019).

Çağdaş sınıf yönetimi yaklaşımlarında, eğitimde başarının öğretmen-öğrenci ilişkisine dayandığı vurgulanmaktadır (Kocatürk, 2019; Nurmi, 2012; Yılmaz ve Tosun, 2013). Bu çerçevede öğretmenin ne öğrettiğinden, nasıl öğrettiğinden veya kime öğretmeye çalıştığından çok daha önemli olan öğretmen-öğrenci arasındaki ilişkinin kalitesi ön plana çıkmaktadır (Gordon, 2008). Eğitimde, öğretmen ve öğrenci arasındaki ilişkinin sağlıklı olmasının öğrencinin bilişsel, duyuşsal ve davranışsal düzey kazanımlarında kritik role sahip olduğu söylenebilir. Sağlıklı bir öğretmen-öğrenci ilişkisinde, öğrencinin değerli olduğunu hissettirme, öğrenciyi dinleme, anlaşılır ve anlamdaş olma, ben dilini kullanma, tutarlı ve nazik olma davranışları oldukça önemli bir yer tutmaktadır (Tofur, 2019). Birey sınıfta sadece ussal bir varlık olarak değil, duygusal ve sosyal bir varlık olarak belirgin, görece değişmeyen ve görece tutarlı özelliklerinin ifadesi olan kişiliği ile yer almaktadır (Demirbolat, 2018). Bu bağlamda öğrenci-öğretmen iletişiminde öğrencinin biricikliğinin öne çıktığı, öğrencinin duyguları, düşünceleri olan bir birey olarak görüldüğü bir sınıf ortamında iletişim ve etkileşimin daha sağl1klı sürdürülebileceği söylenebilir. Etkileşimin temelinde iletişim olduğuna göre, eğitim öğretim etkinliklerinin gerçekleştiği sınıf ortamlarında, öğrenci-öğretmen iletişimi kilit noktada yer alabilmektedir.

Sınıf, eğitim öğretim etkinliklerinin gerçekleştiği ve öğretmen ile akranlar arasında etkileşimin yüksek olduğu bir yaşam alanıdır (Erdoğan, 2011). Sınıf sadece öğrencinin davranışlarını kontrol altına alma adına disipline olduğu yerden öte etkili bir iletişimin gerçekleştiği yerdir (Ekici, 2008). Eğitimin, iletişimin gerçekleştiği sınıf ortamının yönetiminin incelenmesi, öğretmen-öğrenci ilişkilerinin anlamlandırılmasını sağlayabilir. Sınıf yönetimi; öğretim sürecinin yönetilmesi, iletişim ve etkileşim süreçlerinin yönetimi, disiplin ve kuralların yönetimi gibi pek çok boyutu kapsamaktadır (Demirbolat, 2018). Martin ve Baldwin (1993a; 1993b) ise sınıf yönetimini; kişilik, öğretim ve disiplin olmak üzere üç boyutta ele almaktadır. Kişilik boyutunu; öğretmenin öğrenci kişiliği ile ilgili inançları, öğrenci yeteneklerinin arttırılması ve güdülenmesi için yaptıkları oluşturmaktadır. Öğretim boyutu; öğretmenin sınıfta öğrencilerin çalışmalarının ortaya çıkarılması ve sürdürülmesi için yaptığı faaliyetleri içermektedir. Disiplin boyutu ise; öğretmenin sınıfta yapılması kabul edilen davranış ölçütleri meydana getirebilmek için yaptığı çalışmaları ifade etmektedir (Djigic ve Stojiljkovic, 2011). Sınıf yönetiminin amacı, etkili bir eğitim öğretimin gerçekleşmesi için gereken fiziksel hazırlıkların yapılması, gereken materyallerin temin edilmesi ve uygun öğrenme ortamının meydana getirilmesi ve sürdürülmesi olarak ifade edilebilmektedir (Celep, 2002). Sınıfta öğretim ve disiplin boyutlarının başarılı yürütülebilmesinin temelinde öğrencinin tanınması ve öğrenci-öğretmen arasındaki sağlıklı iletişimin kurulması yatmaktadır (Demirbolat, 2018). Bu noktada öğretmenlik ile iletişimin ayrılmaz bir bütün olduğu söylenebilir.

Sınıf ortamı öğrenci, öğretmen, sınıfın fizikî durumu ve bazen de veli faktörünü içinde barındırmaktadır. $\mathrm{Bu}$ faktörlerin etkileşimleriyle ortaya çıan durumlar ve bu durumların yönetim şekli sınıf iklimini etkilemektedir (Ergen, 2018). Sınıf iklimi bazen öğrenme ortamı, sınıf atmosferi ve sınıf çevresi gibi terimlerle de ifade edilmektedir (Salar ve Turgut, 2019). Schmuck ve Schmuck (1978) "sınıf iklimi" terimini, öğretmen- 
Öğretmenlerin Sınıf içi Gündelik Deneyimleri...

öğrenci ve öğrenci-öğrenci etkileşimleri sırasında gerçekleşen tüm grup süreçlerinin tamamı olarak tanımlamaktadır. Bu süreçler; kişilerarası ilişkiler, duygusal dalgalanmalar, öğretme stilinin ve sınıf organizasyonunun yapısal yönleri, öğrencilerin öğretmenden beklentileri ve onlara yönelik tutumları, disiplin sorunları vb. kavramları içermektedir (Güçlü, 2000).

Sınıf yönetiminin boyutlarından biri olan disiplin, akıcı bir öğretim faaliyetinin gerçekleşmesi için gerekmektedir (Bozkurt, 2018). Kapsamlı bir sınıf disiplini programı, etkili sınıf yönetimi ile yanlış davranışı önlemek, öz disiplini geliştirmek, yanlış davranışı düzeltmek, ciddi ve kronik davranış problemlerini tanımlamak boyutlarını içermektedir (Bozkurt, 2018). Sınıf içinde öğrenci davranışları, öğrencilerin kişisel özellikleri, yaşantıları, ihtiyaçlarının karşılanma derecesine göre farklılaşabilmektedir. Bu davranışlar her zaman istendik yönde gelişmemektedir. Bu bağlamda sınıfta ortaya çıkan istenmeyen davranışların yönetilmesi etkili bir eğitim öğretim ortamının oluşturulması için gerekmektedir (Koçak, 2019). İstenmeyen davranış, sınıf düzenini ve eylemlerini bozan, sınıf içinde eğitim-öğretimin amaçlarına ulaşmasını ve zamanın verimli kullanılmasını engelleyen davranışlardır (Başar, 2011). İstenmeyen davranışların önlenmesine ilişkin olarak öğretmenlerin izlediği yaklaşımlar davranışın türüne göre değişmekle birlikte öğretmenler, genellikle dersten sonra öğrenciyle bireysel olarak konuşma, beden diliyle öğrenciyi uyarma, öğrencinin dikkatini yeniden toplama, davranışını durdurmasını isteme ve öğrenciyi sözlü olarak uyarma tekniklerini kullandıklarını belirtmişlerdir (Aksoy, 1999; Celep, 2002). Başarılı öğretmenler sınıftaki bir problemin önlenmesi içi gerekli müdahalenin ne zaman yapılması gerektiğini bilmektedirler. Öğretmenler sorun oluşturan davranışları ortadan kaldırmak için genellikle vücut dilini kullanma veya sınıfta bulundukları konumu değiştirme gibi eylemleri gerçekleştirmektedirler (Marzano, 2003). Öğretmenlerin sınıf yönetimini nasıl sağladığı ve nasıl sürdürdüğü, disiplin boyutunda neler yaptıkları, sınıf içi deneyimlerine odaklanılarak anlaşılabilir.

Öğretmenin davranışları ve rol model olma düzeyi sınıf disipliniyle ilgilidir (Balıkçı 2019). Öğretmen sınıf disiplinini sağlarken sevgi, güven, empati kurma gibi olumlu davranışları sergiliyorsa öğrencilere de olumlu bir model olabilecektir. Öğretmenler öğrencilerinde geliştirmek istedikleri kişilik özelliklerini kendi davranışlarında göstermelidir (Yılmaz, 2017). Öğretmenler bir yandan kurdukları iletişim ile sınıf iklimini etkileyebilmekte, bir yandan da davranışlarıyla öğrencilere örnek olmaktadır (Güçlü, 2000). Okulun temel amacının sınıf içi öğrenmeleri sağlama olduğu düşünüldüğünde alan yazındaki araştırmaların genelde okulun yönetimi, öğretmenlerin örgütsel davranışları, liderlik gibi sınıf dışında gelişen ve sınıfa dolaylı yoldan etkisi olan durumlara odaklandığı söylenebilir. Diğer yandan bu araştırmaların nicel yönteme dayalı ve sonuç ağırlıklı olduğu gözlenmiştir. Buna ek olarak sınıf içi öğretmen deneyimlerine odaklanan çalışmalarda ise ağırlıklı olarak istenmeyen davranışların yönetimi ve bu davranışlarla başa çıkma yolları (Jenkins ve diğerleri, 2009; Lindqvist, ve diğerleri, 2017), öğretmen-öğrenci ilişkisinin akademik başarıya etkisi (Gablinske, 2014; Hallinan, 2008; Hamre, ve diğerleri, 2012), ve öğretmen etkililiği (Harris \& Sass, 2011) gibi belirli boyutlara vurgu yapan konuların ön planda olduğu söylenebilir. Sınıf içi öğrenmelerin sağlanabilmesi için odaklanılması gereken temel noktanın sınıf içi yaşantılar ve deneyimler olduğu düşünülmektedir. Bu çerçevede öğretmenlerin sınıflarında yaşadıkları gündelik deneyimlerini bütüncül bir yaklaşımla irdelemek ve bu deneyimleri nasıl anlamlandırdıklarını ortaya çıkarmak önemlidir.

Bu çalışmanın amacı öğretmenlerin sınıf içi gündelik deneyimlerini irdelemek ve söz konusu deneyimleri nasıl anlamlandırdıklarını fenomenolojik bir yaklaşımla ortaya çıkarmaktır. Bu amaç doğrultusunda öğrencilerle olan iletişim ve etkileşime, sınıf yönetimi süreçlerine ve öğrenme ortamına ilişkin öğretmenlerin sınıf içi gündelik deneyimleri irdelenmiştir.

\section{Yöntem}

\section{Araştırmanın Deseni}

$\mathrm{Bu}$ çalışmada nitel araştırma desenlerinden fenomenoloji kullanılmıştır. Fenomenoloji, insanların, toplumların ya da toplulukların deneyimlerinden çıkardıkları anlamların nasıl ortaklaştığına, deneyim sürecinden ziyade bu deneyimlere ilişkin kişilerde kalan anlama odaklanılmasıdır. Belli bir zaman ve yer 
sınırlaması olmadan deneyimlerin özünün anlamlandırılmasıdır (Denzin \& Lincoln, 1994). Bu çalışmada öğretmenlerin sınıf içi gündelik deneyimleri irdelenmiş ve bu deneyimleri nasıl anlamlandırdıkları ortaya çıkarılmıştır.

\section{Çalışma Grubu}

Bu araştırmanın çalışma grubunu, öğretmenler oluşturmaktadır. Araştırmanın katılımcıları, Millî Eğitim Bakanlığına bağlı kamu okullarında çalışan 5 öğretmenden oluşmaktadır. Katılımcılar, amaçlı örnekleme türlerinden tipik örnekleme yöntemi ile belirlenmiştir. Katılımcıların deneyimlerinin önemli olduğu bu araştırmada, katılımcıların meslekte kıdemlerinin en az 10 yıl olması bir kriter olarak belirlenmiştir. Ayrıca katılımcıların Millî Eğitim Bakanlığına bağlı kamu okullarında görev yapan öğretmenler olmasına dikkat edilmiştir. Katılımcıların isim ya da çalıştıkları kurum gibi doğrudan kimliklerine işaret eden bilgiler çalışma kapsamında değiştirilerek sunulmuştur. Çalışma grubuna ilişkin bilgiler Tablo 1'de sunulmuştur.

Tablo 1. Çalışma Grubu

\begin{tabular}{|c|c|}
\hline Ali & $\begin{array}{l}41 \text { yaşında, evli, iki oğlu var. } 2 \text { yıl dershane, } 2 \text { yıl Anadolu Lisesi, } 17 \text { yıl da Anadolu İmam Hatip Lisesi'nde olmak } \\
\text { üzere } 21 \text { yıllık matematik öğretmenlik hayatı var. Öğretmenliğini baba olmadan önce ve baba olduktan sonra } \\
\text { olmak üzere iki döneme ayırıyor. }\end{array}$ \\
\hline Ayşe & $\begin{array}{l}\text { Sınıf Öğretmenliği } 2004 \text { yılı mezunu, evli, iki oğlu var. } 2 \text { yıl ek ders ücreti karşılığında geçici süreli öğretmenlik } \\
\text { yaptı, } 2006 \text { yılında Bitlis'e atandı. } 15 \text { yıldır kadrolu öğretmen olarak çalışıyor. Çocuğunun ilkokul 1'e başladığ1 } \\
\text { dönemde kendisinin de ilkokul } 1 \text { 1. sinıfları okutuyor olmasını öğretmenlikte dönüm noktası olarak } \\
\text { değerlendiriyor. }\end{array}$ \\
\hline Fatma & $\begin{array}{l}\text { Sınıf Ö̆̆retmenliği } 2006 \text { yılı mezunu, evli, iki çocuğu var. } 15 \text { yıldır kadrolu öğretmen olarak çalışıyor. } \\
\text { Öğgretmenliğinin ilk yılında akademik bilginin değil de deneyimin çok daha önemli olduğunu gördüğu zamanı, } \\
\text { öğretmenlikte dönüm noktası olarak nitelendiriyor. }\end{array}$ \\
\hline Fatih & $\begin{array}{l}\text { Tarih Bölümü mezunu, } 2003 \text { yılında göreve başlamış, } 2006 \text { yılından beri de kadrolu öğretmenlik yapıyor. Evli, } \\
\text { iki kızı var. Öğretmenliğe atandığı ilk dönem, birkaç kez okula geç kaldığında okul müdüründen öğretmenlerin } \\
\text { devamsızlık hakkının olmadığı uyarısını aldığ1 günü meslekte dönüm noktası olarak nitelendiriyor. }\end{array}$ \\
\hline Defne & $\begin{array}{l}\text { Okul Rehber Öğretmeni, Rehberlik ve Psikolojik Danışmanlık Ana Bilim Dalı (RPD) Bölümü } 2009 \text { mezunu, } 2010 \\
\text { yılından beri öğretmenlik yapıyor. Evli, iki kızı var. Aldı̆̆ı her mesleki eğitimi meslekte dönüm noktası olarak } \\
\text { görüyor. }\end{array}$ \\
\hline
\end{tabular}

Çalışma grubunun genel özellikleri incelendiğinde katılımcıların evli ve çocuk sahibi oldukları ve meslekte kıdemlerinin en az 10 yıl olduğu söylenebilir.

\section{Veri Toplama Aracı}

Çalışmada veriler, yarı yapılandırılmış görüşme formu ile elde edilmiştir. Alan yazından elde edilen bilgiler doğrultusunda görüşme formu hazırlanmış, alan uzmanlarının eleştiri ve önerileri doğrultusunda forma son hali verilmiştir. Görüşme formundaki sorular, katılımcılardan daha detaylı bilgiler alabilmek için çeşitli sonda sorularla desteklenmiştir. Örneğin; a) Sıradan bir günde bir ders saatinizi, sınıfa girme anınızdan itibaren anlatabilir misiniz? a1) Nasıl girersiniz, ilk önce ne yaparsınız, öğrenciler ne yapar, nasıl başlarsınız, neler konuşursunuz? b) Tüm öğrencilerinizin bildiği ve sınıf içinde uymak zorunda olduğu, yalnızca size ait belirli prensip ya da kurallarınız var mıdır? b1) Öğretmenin kuralıdır bu dedikleri bir şey? b2) Öğrenciler bunlara riayet etmediği zaman ne olur? gibi sorular sorulmuştur. Amaçlı örnekleme yöntemiyle belirlenen katılımcılarla görüşme öncesi telefonla iletişim kurulmuş, çalışmayla ilgili kısa bilgiler verilmiş ve her birinden randevu alınmıştır. Görüşmeler katılımcıların izniyle kaydedilmiş ve analiz için transkripsiyon yapıldıktan sonra tekrar görüşmecilere elektronik posta yoluyla iletilmiştir. Bu noktada görüşmecilerden düzeltmek istedikleri, yanlış anlaşılmaya sebep olabilecek ya da eksik olduğunu düşündükleri ifadeleri gözden geçirmeleri istenmiştir. Son olarak gerekli düzeltmelerden sonra katılımcıların onayladıkları transkripsiyonlar, değerlendirme sürecine alınmıştır.

\section{Verilerin Analizi}

Verilerin çözümlenmesinde içerik analizi tekniği kullanılmıştır. Öncelikle, ham veriler, araştırmacılar tarafından okunmuş, verilen cevaplarda ortak noktalar bulunmuş, ayrı ayrı kodlar oluşturulmuş, kodlardan yola çıarak alt temalara ulaşılmıştır ve veriler betimsel bir anlatımla sunulmuştur. Bu süreçte NVivo 12 nitel 
veri analizi programından yararlanılmıştır. Tema, alt tema ve kodlar, bulguların daha kolay anlaşılabilmesi için tablo haline getirilmiş ve tablolardaki veriler katılımcı cevaplarıyla doğrudan desteklenmiştir.

\section{Geçerlik ve Güvenirlik}

Nitel araştırmalarda geçerlik, çalışmanın inandırıcılığını ve aktarılabilirliğini sağlamaya yönelik süreçleri kapsamaktadır (Lincoln \& Guba, 1985). Bu çerçevede çalışmanın inandırıcılığını (iç geçerlik) artırmak ve aktarılabilirliği (dış geçerlik) sağlamak için izlenen çeşitli stratejilere değinilmiştir. Nitel araştırmalarda iç geçerlik, çalışma bulgularının inandırıcılık ve özgünlük bağlamında değerlendirilmesi ile ilgilidir (Miles ve Huberman, 1994). Çalışma kapsamında inandırıcılığı sağlamak için katılımcı teyidi alınmıştır. Katılımcı teyidi; katılımcılara verinin özgünlüğü ve doğruluğunu onaylamaları bağlamında aktif bir rol vermesi açısından önemlidir (Creswell, 2002). Bu doğrultuda yapılan görüşmeler, katılımcıların izniyle kaydedilmiş ve transkripsiyon yapıldıktan sonra tekrar görüşmecilere elektronik posta yoluyla iletilmiştir. Bu noktada görüşmecilerden düzeltmek istedikleri, yanlış anlaşılmaya sebep olabilecek ya da eksik olduğunu düşündükleri ifadeleri gözden geçirmeleri istenmiştir. Son olarak gerekli düzeltmelerden sonra katılımcıların onayladıkları transkripsiyonlar veri olarak kullanılmıştır. Nitel çalışmalarda diş geçerlik, çalışma bulgularının farklı bağlamlara aktarılabilirliğine ilişkindir (Lincoln \& Guba, 1985; Yin, 2003). Nitel çalışmalarda, konuya ilişkin bir perspektif sunma ya da genellemelerden çok, bağlam temelli yorumlar üretme ön plandadır (Patton, 1990). Sunulan perspektifin ya da üretilen yorumların başka ortamlara aktarılabilirliğini okuyucu ve yararlanıcılar değerlendirebilir. Bu çalışma kapsamında okuyucunun bağlamdan uzaklaşmaması için katılımcı ifadeleri doğrudan alıntılanmıştır. Nitel araştırmalarda güvenirlik, araştırma sürecinin ve bulguların açık ve anlaşılır şekilde sunularak dış değerlendiricilerin araştırmanın tutarlılığını kontrol edebilmesine imkân verecek şekilde planlanmasıdır (Lincoln \& Guba, 1985). Bu çalışmada araştırmanın; deseni, çalışma grubu, veri toplama araçlarına ilişkin bilgiler ve analiz süreci detaylı olarak sunulmuştur. Analiz sürecinde öğretmenlerin sınıf içi gündelik deneyimlerine ilişkin genel bilgiler ve görüşme verilerinden, kod ve alt temalar araştırmacılar tarafından oluşturulmuştur. Bunun yanı sıra çok fazla yorum içermeyen bulgular bölümü, görüşme analizlerinden yapılan doğrudan alıntılarla desteklenmiştir. Tartışma bölümünde ise elde edilen bulguların alan yazındaki çalışma bulgularıyla olan ilişkileri değerlendirilmiştir.

\section{Bulgular}

Çalışma kapsamında bulgular değerlendirildiğinde "Frekansı yakalamak önemli", "Sınıf içi otorite sağlamanın yolları", "Öğretmen de öğrenci de sınırları aşmamalı" ve "Öğretmenin müdahalesi var ama sınırlı" olmak üzere 4 alt temanın ortaya çıtığı söylenebilir. Çalışmanın amacı doğrultusunda öğrencilerle olan iletişim ve etkileşime, sınıf yönetimi süreçlerine ve öğrenme ortamına ilişkin öğretmenlerin sınıf içi gündelik deneyimleri katılımcıların konuyla ilgili verdikleri bilgilerle ilgili tema ve alt temalar Tablo II'de sunulmuştur.

Tablo 2. Bulgulara İlişkin Tema, Alt Temalar ve Kodlar

\begin{tabular}{lll}
\hline Tema & Alt Temalar & Kodlar \\
\hline $\begin{array}{l}\text { Sınıf içi gündelik } \\
\text { deneyimler }\end{array}$ & Frekansı yakalamak önemli. & Olumlu bă̆, model olmak, iletişim \\
& Sınıf içi otorite sağlamanın yolları. & Bilgi, sevgi ile otorite, sarsılan otorite. \\
& Öğretmen de öğrenci de sınırları aşmamalı. & $\begin{array}{l}\text { Öğretmen-öğrenci sınırı, Sınır ihlali, mesafe, } \\
\text { kişisel alan. } \\
\text { Öğretmen tepkileri, iyi örnek } \\
\text { olmak, hızlı tepki. }\end{array}$ \\
\hline
\end{tabular}

\section{Frekansı Yakalamak Önemli}

Çalışma kapsamında yapılan görüşmeler sonucu sınıf içi olumlu iletişimin temel bir unsur olduğu ve iletişimin öğretmenlerin gündelik deneyimlerinde merkezi bir konumda olduğuna yönelik veriler elde edilmiştir. Bu çerçevede öğretmenler öğrencilerle doğru, sağlıklı ve olumlu bir iletişim biçimi geliştirmenin olumlu sınıf iklimi oluşturma ve sınıf içi öğrenmeleri daha kalıcı hale getirmek için gerekli olduğunu belirtmişlerdir. Öğretmen-öğrenci ilişkilerini Ali şu şekilde belirtmiştir:

Öğrencilerle tatlı sert bir ilişkimiz vardır. Çocuklar benim neye, ne zaman kızacağımı bilirler. Özellikle şu an çalıştı̆̆ım 
okuldaki öğrencilerle hazırlık dâhil olmak üzere beşinci yılımız. Hani ben nerde, neye kızacağım, bunu çok iyi bilirler. Ben şöyle derim. Mesela, öğrencimizin adı Ali. "Ali sana sevgilerimi gönderiyorum" derim. Çocuk da "aldım hocam" der, tamam, yoluna devam eder. Notla tehdit, matematik öğretmeninin notla tehdidi ben çok mantıklı bulmuyorum.

Bu ifadelere benzer şekilde Fatih, sınıf içi bağlamda yaşadığı deneyimleri şu şekilde aktarmıştır.

Despot bir öğretmen değilim, çocukların hepsiyle samimi ilişkiler kurmaya çalışırım. Ama çocuklar da bilir, "hocanın bir sınırı var, onu aşarsak evet biraz tersliyor". Sert davranmam, hâl hatır sorarım, bir arkadaş gibi, yanlış oluyor ama gerçekten bir öğretmen öğrenci ilişkisinde olması gereken sıcak, samimi ilişkiyi kurmaya çalışırım. Çocukla çok resmi olmayı da sevmem. Çünkü öğrenciler, sonuç itibariyle okula gelince, bazen anne babasının yerine koyuyor bizi ve bir şeyler paylaşmak istiyor, bir sıkıntısını, bir derdini.

Katılımcıların odaklandıkları noktalar irdelendiğinde, öğretmen ve öğrenci ilişkilerinde denge unsurunu gözetmenin önemli olduğu, öğretmen ve öğrencinin birbirini çok iyi tanıması gerektiği ve öğrenciye verilen değerin hissedilir olmasının sınıf içi iletişim sürecinde önemli olduğu söylenebilir. Buna ek olarak Defne “Siz çocukla o kadar iyi bir iletişimi kurmaya başlayınca, kendini anlatabildiği, derdini, sıkıntısını anlatabildiği, kendinin anlaşıldığı bir öğretmen oluyorsunuz. O zaman çok daha farklı oluyor." ifadeleriyle öğrenciyle kurulan sağlıklı iletişimin öğrencinin kendini ifade edebilme becerisine büyük katkı sağladığını vurgulamıştır.

\title{
Sınıf İçi Otorite Sağlamanın Yolları
}

Çalışma kapsamında yapılan görüşmeler sonucu sınıf içi gündelik deneyimlerde sınıfta otorite kurmanın önemli bir yere sahip olduğuna dair veriler elde edilmiştir. Bu bağlamda öğretmenler sınıfta veya öğrenciler üzerinde kurdukları otoritenin, sınıfın yönetimini olumlu yönde etkilediğini ve öğrencilerin dikkatlerinin öğretim üzerine yoğunlaştırılması için gerekli olduğunu belirtmişlerdir. Sınıf içi otorite sağlama sürecinde öğretmenin mesleki ve alan bilgisinin önemli olduğunu belirten katılımcılardan Ali, "Yani şöyle söyleyeyim. Önce bilgisiyle otorite kurar. Bilmiyorsa, öğrenci öğretmenden fazla bildiğini düşünüyorsa otorite kuramaz." ve Ayşe "Her yaş grubuna göre tabi bilginin yoğunluğu ve farklılıkla çocukta saygı ve otoriteyi de beraberinde getirdiğini düşünüyorum. Bilgi donanımı. O bilgi donanımını da nasıl, ne şekilde, nerede kullandı̆̆ımız önemli" ifadelerini kullanmıştır. Benzer şekilde Defne:

\begin{abstract}
Bilgi, öğrenciyi anlayan bir dil. Öğrenciyi yargılayan yeren böyle aşağılayıcı bir dil vardır. Bunu bazen disiplinle karıştırır öğretmen. Bu dilin dışında öğrenciyi kavrayıcı, onu anlayıcı bir dil, üslup çok önemli. Onun dışında öğretmen alana da hâkim olacak. Bu çok başka bir şey. Sınıf yönetimi de çok önemli bunda. Hem bilgi, hem sınıf yönetimi.
\end{abstract}

Katılımcı ifadeleri, sınava dayalı seçme ve yerleştirme sisteminin oluşturduğu baskının öğretmenlik mesleğini alan bilgisine indirgediği ve bilişsel alana vurgu yapıldığı yönünde bir gösterge olarak düşünülebilir. Diğer yandan otorite sağlama sürecinde duyuşsal ve davranışsal alanların daha önemli olduğunu vurgulayan katılımcilardan Fatma, "Sevgiyle bence tamamen sevgiyle. Çocuklar sizi seviyorsa otorite kurulmuş oluyor. Sevmek, eleştirmemek." ifadeleriyle sınıf içi otoritenin sevgiyle kurulabileceğini, Fatih ise öğretmenin davranışlarıyla rol model olma durumuna vurgu yaparak otorite sağlanabileceğini belirtmiştir.

\footnotetext{
Burada duruşunun çok etkili olduğunu düşünüyorum. Bir de öğrenci kılık kıyafetiyle düzgün bir öğretmen istiyor. İfade tarzıyla, yani yerel bir ağızla konuşacağımız zaman çocuklar da bizimle yerel ağızla konuşuyor. Ya bu bazen aradaki saygınlığı bozabiliyor. Bu çok önemli, konuşma-üslup. Kılık kıyafet, duruşumuz, kendimize bakışımız, dağınık bir saç değil derli toplu saç, öz bakımlarını yapmış, tırnak uzun değil. Ya bu çok önemli. Çocuğun başta gördüğü fiziksel duruş.
}

Sınıf içi öğrenmelerin hedeflendiği şekilde gerçekleşmesi için otorite sağlamak önemlidir. Katılımcı ifadeleri incelendiğinde otorite sağlama sürecinde deneyimlerin farklılık gösterdiği, bazı katılımcıların öğretmenlik mesleğinin bilişsel boyutuna, bazılarının ise duyuşsal ve davranışsal boyutlara daha fazla önem verdiği ve söz konusu boyutlar çerçevesindeki pratiklerle sınıf içi otorite sağlamaya çalıştıkları söylenebilir. Katılımcı deneyimlerinin yoğunlaştığı bir başka nokta da öğretmen-öğrenci ilişkilerinde unutulmaması ve ihlal edilmemesi gereken mesafedir.

\section{Öğretmen de Öğrenci de Sınırları Aşmamalı}

Çalışma kapsamında katılımcılar, öğretmen-öğrenci arasındaki mesafenin oldukça önemli ve sınıf içi gündelik pratikleri belirleyici bir role sahip olduğuna ilişkin ifadeler kullanmışlardır. Söz konusu mesafe, sınır, kişisel alan ya da özel alanın öğretmen ve öğrenci ilişkilerini şekillendirici bir özelliğe sahip olduğu söylenebilir. Bu konuda Ali, öğretmenliği sürecinde gözlemlediği öğrenci davranışlarındaki değişiklere vurgu yapmıştır. 
İlk mesleğe başladığım yıllarda Bitlis'te göreve başladım. Orda mesela çocuk bizi çarşıda da görse önünü iliklerdi. Bunu bir saygı ibaresi olarak nitelendirirdik. Şimdi devir o kadar değişti ki çocuklarda ceket bile yok. Şu an çocuk öğretmenle nasıl konuşacağını bilsin. Mesela kimi öğrenci var, öğretmeniyle senli benli konuşur ki bunu hiç tasvip etmem çünkü arada bir duvar olması lazım, bana senli benli hitap etmemeli. Saygısızlık olarak bunu nitelendirebilirim. Yüksek sesle konuşmamalı. Çünkü ben öğrencimin kendisiyle yüksek sesle konuşmuyorsam öğrenci de benimle konuşmamalı (Ali).

Benzer şekilde Fatih ve Defne, geleneksel değerlere yaptıkları vurgu ile birlikte öğretmen-öğrenci ilişkilerinde öğretmenin de üzerine düşen sorumluluklarının olduğu yönünde ifadeler kullanarak karşılıklılık unsuruna değinmişlerdir. Diğer bir deyişle, öğretmen ve öğrenci arasında bir sınırın görünmez ama hissedilir olması gerektiği ve bu sınırın oluşmasında öğretmene büyük sorumluluk düştüğü söylenebilir.

Toplum içerisinde sahip olduğumuz kültüre, örf ve âdete göre, işte yine dediğim gibi, büyüğe sayg1, küçüğe sevgi. Şimdi biz öğrencilerimizi seviyor olsak, onlar da bize saygı gösteriyor. Burada karşılıklı bir ilişki var. Ama biz onları severken, işin boyutunu ilerletir, çocuklara bütün kapıları açarsak, çocuklar bunu aşıyorlar, çiğniyorlar. Bazen arkadaşına yapacağı şakayı yapıyor bize. Yani orda bi çizgiyi göstermek lazım. "Bana şunu diyemezsin, bana şunu yapamazsın". Belki ifade etmesek de çocuğa duruşumuzla göstermemiz lazım. Yani "ben bu hocaya bunu söylersem, kırılır". O şekilde bir ilişki belirliyorum. Ama bunu nasıl yapıyorum? Tam emin değilim. Ama çocuk bana şaka yapmıyor. Yaparsa da diyorum ki "bunu arkadaşına yap, ben senin arkadaşın değilim. Bu şakayı bana yapma. Arkadaşına yap"' (Fatih).

Ben özel hayatın önemli olduğunu düşünüyorum, öğretmen hayatının, öğretmenle öğrenci ilişkisinde. Sınırın, hitap şeklinin. Bana öğrenci her şeyini rahatlıkla anlatabilmeli. Ama saygı ifadelerinden yoksun, senli benli konuşamamalı. Çünkü ben de ona "sen" demiyorum, ismiyle hitap ediyorum. Ya da diyalog şekli, espri seviyesi. Size nasıl konuşuyor, bir argo ifade de bulunabiliyor mu? Bunlar sınır bence. Yani öğretmen farkı olmalı. Onun bir arkadaşından, akrabasından, anne babasından çok farklı bir yerde olmalı. Bu saygının kişiye değil, öğretmenlik mesleğine de olduğunu düşünüyorum. Burada da belirleyici olan öğretmenin öğrenciye hitabı (Defne).

Öğretmen öğrenci ilişkilerindeki mesafeye ilişkin diğer katılımcıların ifadelerini destekleyen Fatma, ilişkilerde kararlı ve tutarlı olmanın da çok önemli olduğunu belirterek farklı bir noktaya daha vurgu yapmıştır.

Aslında öğretmenin bir sınırı olduğu gibi öğrencinin de bir sınırı var. Yani kimse, öğretmen de öğrencinin, öğrenci de öğretmenin o çizgisini aşmaması gerekiyor. Dediğim gibi, ben biraz daha küçük çocuklarla çalıştığım için, büyük olsalardı farklı düşünürdüm. Ama küçük olduğu için biraz daha çocuklar o sınırı pek şey yapamıyorlar. Bir güler yüz, tatlı dil gördükleri anda, böyle bir anne gibi o sınırı zorluyorlar. Orda da şey devreye giriyor, "Sizin kararlı duruşunuz." "Bak ben bundan hoşlanmıyorum diye kararlı durduğunuz anda", "Ha öğretmen bundan hoşlanmıyor" diyor ve o sınırı geçmiyor (Fatma).

İnsan ilişkilerinde belirleyici bir role sahip olan kararlılık ve tutarlık ilkeleri, iletişimin en yoğun yaşandığı yerlerden olan sinıfta da öğretmen öğrenci ilişkilerini düzenlemede önemlidir. Fatma, öğretmen öğrenci ilişkilerinde sınırın ihlal edilmemesi için öğretmenin kararlı tutumunun önemine vurgu yapmıştır. Özetle, öğretmenlerle öğrenciler arasında oluşturulan mesafenin karşılıklı saygıyı geliştirdiği ve olumlu sınıf iklimi oluşmasına katkı sağladığı söylenebilir.

\section{Öğretmenin Müdahalesi Var Ama Sınırlı}

Sınıf içi gündelik deneyimlerin diğer bir boyutu, öğrencilerin istenmeyen davranışlarının yönetilmesi ile ilgilidir. Sınıf içinde öğrenci davranışları, öğrencilerin kişisel özellikleri, yaşantıları, ihtiyaçlarının karşılanma derecesine göre farklılaşabilmektedir. Bu davranışlar her zaman istendik yönde gelişmemektedir. Çalışma kapsamında katılımcılar, istenmeyen davranışlarla ilgili sınıf içi yaşadıkları deneyimlere ve söz konusu davranışları yönetme sürecinde kullandıkları yöntemlere değinmişlerdir.

Ali, sınıf içinde istenmeyen bir davranış oluştuğunda şu şekilde davrandığını belirtmiştir.

Ben susarım, sessizce o bölgeye bakarım. Ta ki, o bölgedeki öğrencinin dikkatini çekene kadar. Sınıfta sessizlik oluştuğu için, şimdi normalde ben anlatırken sınıfta bir gürültü oluşacağı için, öğrenci şey yapar, sessizlikten bir şüphelenir, döner bakar, göz göze geliriz. Hemen kendine çeki düzen verir. Yani sınıfta rencide etmem. Genellikle de olanı söylüyorum. Çocuk dışarı gelir, "Ya hocam kusura bakmayın, özür dilerim, yanlış yaptım" falan diye. Çünkü lise öğrencisiyle muhatap olduğumuz için şimdi çocuğun onurunu kırıcı bir cümle kurduğunuz zaman sert tepki verebilir.

Ali sınıfta ders anlatırken gürültü gibi istenmeyen davranışlar meydana geldiğinde dikkat çekmek için sessiz kalmayı tercih etmektedir. Diğer yandan öğrencilerin gelişim dönemlerini dikkate alarak daha dikkatli davrandığını belirtmiştir. Benzer yöntemleri uygulayan Fatih ise yaşadığı deneyimleri şu şekilde aktarmıştır.

Evet yani önce genellikle şu oluyor. Yüksek sesle bir uyarıorum. Ama devam ediyorsa veya sonra bir daha devam ettiyse, 
ben susuyorum. Büyük bir sessizlik oluyor. Sonra benim sesimin çıkmadığını gören öğrencilerin ilgisini çekiyor ve herkes bana doğru dönüyor. "Evet bunu istiyorum" diyorum. Konuşarak çekemediğimiz ilgiyi bazen susarak, sessiz kalarak çekiyoruz. Sessiz kaldığımızda daha etkili olduğunu düşünüyorum. Mesela ben anlatırken, "Oğlum bak sen yüksek sesle konuşuyorsun, bağırıyorsun, dikkatim dağılıyor". O da "Sen dersini anlat, bana karışma" diyorsa, ben bunu büyük bir saygısızlık olarak görüyorum. Bunu yaşıyoruz, bazen yaşıyoruz. Ya öyle dediği zaman da genelde orda bir tepki koyuyorum. İşte "Burada bir tek sen değilsin, burası eğitim yuvası, burada işlememiz gereken bir müfredat var, kimse bunu engelleyemez, bu konuda engel çıkartacak olursan senin hakkında disiplin işlemi başlatırım." Yapabileceğim bu. Böyle bir tedbir almaya çalışıyoruz.

Fatih, Ali'den farklı olarak disiplin mekanizmasını gündeme getirerek istenmeyen öğrenci davranışlarını engellemeye çalıştığını ancak yapabilecek daha fazla bir şeyinin olmadığını belirterek öğretmenlik mesleğinde yetki ve sorumluluk dengesizliğine işaret etmektedir. Öğretmenin öğretme gibi önemli bir sorumluluğu varken, öğrenme ortamını engelleyici davranışlar sergileyen öğrenciler için disiplin dışında herhangi bir yaptırımının olmaması yetki ve sorumluluk dengesizliğini gündeme getirmektedir. Bu konuya dikkat çeken bir başka katılımcı da sınıf içinde karşılaşılan istenmeyen davranışlara yönelik öğretmenin müdahale şansının çok sınırlı olduğunu vurgulamıştır.

Çok sınırlı. Çünkü o sizin çocuğunuz değil. Sizin çocuğunuz olsa bile müdahaleniz sınırlı. O bir birey artık, farklı bir birey. Öğretmenin müdahalesi sınırlı. Konuşup uyarabilir, veliyle görüşebilir, veliyle ortak hareket edebilir. Ama ondan sonrası için artık müdahale edecek bir şeyi yok. Size değer veren bir veliyse sizinle oturup konuşur ve ortak hareket eder. Değer vermeyen bir veliyse, kendi çok bilmişse, o zaman sizi dinlemez (Fatma).

Katılımcı ifadelerinden anlaşıldığı gibi sınıf içi gündelik hayatta istenmeyen öğrenci davranışları her zaman meydana gelebilmekte ve çok fazla olduğunda öğrenme ortamını olumsuz etkileyebilmektedir. Diğer yandan katılımcıların bu davranışlara yönelik yaptırımlarının sınırlı olması ya da velinin destek sunmaması gibi durumlar söz konusu müdahaleleri daha kısıtlı hale getirebilmektedir. Bu bağlamda katılımcılar, istenmeyen davranışları yönetme sürecinde etkili iletişim becerilerinin, ses tonunun, jest ve mimiklerin, rol model olmanın önemli bir yere sahip olduğunu belirtmişlerdir.

\section{Sonuç ve Tartışma}

Çalışma kapsamında öğretmenlerin sınıf içi gündelik deneyimlerine ilişkin görüşleri değerlendirildiğinde "Frekansı yakalamak önemli”, "Sınıf içi otorite sağlamanın yolları”, "Öğretmen de öğrenci de sınırları aşmamalı” ve "Öğretmenin müdahalesi var ama sınırlı" olmak üzere 4 alt temanın ortaya çıktığı söylenebilir. Katılımclarla yapılan görüşmelerden elde edilen bulgular ışı̆̆ında "Frekansı yakalamak önemli" alt temasında katılımcıların sınıf içi gündelik deneyimlerinde öğrencilerle ilişkilerinde iletişimi merkezi bir konumda gördükleri tespit edilmiştir. Çeşitli araştırmalarda bu tespiti destekleyecek çalışmalara rastlanmıştır. Sınıf yönetiminin temelini öğretmen-öğrenci iletişimi oluşturmaktadır (Turan, 2020). Eğitimin iletişim olmadan gerçekleştirilmesi mümkün gözükmemektedir (Tofur, 2019). Eğitimde hedeflenen kazanımlara ulaşılması ile öğretmenin iletişim becerileri arasında doğru bir orantı vardır (İhtiyaroğlu, 2018). Öğretmen- öğrenci ilişkilerinde sağlıklı iletişim ve etkileşim olumlu sınıf iklimine katkı sağlamakta oldukça önemli bir yere sahiptir (Conroy, ve diğerleri, 2009). Olumlu sınıf iklimi oluşturmak için öğretmen, öğrencileriyle kendilerini rahat ifade edebilecekleri bir iletişim tarzı geliştirmelidir (Blass, 2018). Öğretmenlik iletişimin temelde yer aldığı, etkileşim üzerine kurulmuş bir meslektir (Yılmaz, 2017). Etkili sınıf yönetiminin en temel ilkesi, öğrencilerle etkili iletişim kurmaktır (Wragg \& Dooley, 1984). Katılımcılar, samimi, sağlıklı bir iletişim ve öğrenciye değer verme yoluyla olumlu bir sınıf iklimi oluşturmaya çalıştıklarını belirtmişlerdir. Bu çerçevede öğrencilerin kendilerini daha rahat ifade edebildikleri, öğretmenleri tarafından anlaşıldıklarını hissettikleri ve olası problem durumlarında öğretmenleriyle iletişime geçme yolunu seçtikleri vurgulanmıştır. Sınıfta öğrenci ve öğretmen arasında oluşan olumlu iletişim ve etkileşimin öğretmenin sınıf yönetim başarısına da katkı sağladı̆̆ı söylenebilir. Öğrencisini anlayabilen ve empati kuran bir öğretmen sorunlara çözüm bulma konusunda daha başarılı olmaktadır (Morgan, 1977). Öğretmen öğrencilerine karşı açık sözlü olmalı, onlara önem verdiğini göstermeli, onların güvenini kazanabilmelidir (Yılmaz, 2017). Katılımcıların ifadeleriyle araştırma bulgularının birbirini destekler nitelikte olduğu söylenebilir. Etkileşim ve iletişim süreçlerinin başarısı, öğretmen ve öğrenciler arasında güçlü ilişkilerin oluşmasının yanında, öğretmen ve öğrencilerin bireysel düzeydeki mutluluk, performans ve bireysel verimliliklerine de önemli katkılar sağlamaktadır (İhtiyaroğlu, 2018). Alan yazındaki çalışmalarla benzer şekilde 
Öğretmenlerin Sınıf içi Gündelik Deneyimleri...

katılımcılar da kurdukları olumlu iletişim ile öğrencilerinin hayatında bir öğretmenden daha fazlası olduklarını, bazen anne-babanın yerine koyulabildiklerini ifade etmişlerdir. Öğretmenlerin öğrencileriyle ilişkilerinde sadece bilgi aktaran değil sorunlarını çözen, onları dinleyen bir öğretmen olmanın önemine vurgu yaptıkları tespit edilmiştir. Katılımcların öğrencileriyle sınıf içi iletişimlerinde arkadaşça ama arkadaş olmadan ilişkilerini kurmak istediklerini belirttikleri saptanmıştır. Bu durum öğretmenin öğrencilerine yönelik arkadaşça davranmasının önemini gündeme getirirken, öğretmen öğrenci ilişkilerinde sınırın da ihlal edilmemesi gerektiğini göstermektedir (Çelik, 2009).

Katılımcılarla yapılan görüşmeler doğrultusunda "Sınıf içi otorite sağlamanın yolları" alt temasında katılımcıların sınıf içi gündelik deneyimlerinde öğrencilerle ilişkilerinde öğretmenlik mesleğinin farklı boyutlarını göz önünde bulundurarak kendi davranışlarını şekillendirdikleri ve sınıf iklimini oluşturdukları söylenebilir. Gonder ve Hymes (1994) okul iklimini; akademik boyut, sosyal boyut, fiziksel boyut ve duygusal boyut olarak dört boyutta incelemişlerdir. Akademik boyut; kurumsal kuralları, okul işleyişini, öğrenci gelişiminin takip edilmesini, ödüllerin olmasını, disiplinli bir ortamı ve yüksek akademik beklentiyi içermektedir. Sosyal boyut; öğrenciler ve öğretmenlerin iletişimlerini ve okul içindeki etkileşimi içermektedir. Fiziksel boyut; okulun fiziksel yönlerini içerir. Duygusal boyut; okul ile ilişkisi olan bütün bireylerin duygu ve davranışlarını içerir. İlk üç boyut okulun iklimini doğrudan etkilemekle birlikte son boyut olan duygusal boyutun bütün boyutların temelinde yer alan ve hepsini kapsayan bir boyut olduğu söylenebilir. Çakmak (2019) ve Gareth (2014) de sınıf iklimini meydana getiren etmenler olarak sınıfın sosyal, psikolojik ve fiziksel yapısıyla ilgili etmenler üzerinde durmuşlardır. Öğrenciler sınıfta sadece bilişsel yönüyle değil duygusal ve sosyal yönüyle de yer almakta, öğrencilerin akademik olarak amaçları birbirine yakın olsa da duygusal, sosyal olarak beklentileri, alışkanlıkları birbirinden farklılık göstermektedir (Demirbolat, 2018). Sınıf içi gündelik deneyimler irdelenirken de öğretmenlerin öğrencilerin sadece akademik yönünü değerlendirmedikleri, bu çalışmalarla benzer şekilde duygusal, sosyal yönlerini de göz önünde bulundurdukları tespit edilmiştir. "Sınıf içi otorite sağlamanın yolları" alt temasında ayrıca sınıf içi gündelik deneyimlerde sınıfta otorite kurmanın önemli bir yere sahip olduğuna dair veriler elde edilmiştir. Bu otoriteyi kurarken rol model olmanın, bilgi ve sevginin ön plana çıtığı̆ tespit edilmiştir. Bireylerin öğretmenlik mesleğini yapabilmek ve sınıfta otorite kurabilmek için; öğretmen yeterlilikleri olarak da nitelendirilebilen bilgi, beceri, tutum, davranış ve değerlere sahip olması gerekmektedir (Yılmaz, 2017). Sınıfta disiplin modellerinden biri olan Kounin modeline göre, öğrenci-öğretmen iletişiminde sevgi, saygı gibi değerler başat rol oynarsa sınıfta disiplin sağlanabilir (Balıkçı, 2019). Bireyler gelişim sürecinde başkalarını onay ve sevgilerini aramakta, bu beklentilerine cevap verilmesi veya verilmemesi insan davranışlarının olumlu veya olumsuz şekillenmesine sebep olmaktadır (Horney, 1991). Çocuk sevgisi, çocukların akademik, sosyal ve kişisel gelişimlerine katkı sağlama isteği öğretmenliğin en önemli özellikleri arasında yer almaktadır (Arslan, 2013). Sınıf içi otorite kurmanın temelinde öğretmenin alanında donanımlı olması, öğrencilere rol model olması ve sevgi yer almaktadır (Balıkçı, 2019). Bu bulgulara benzer şekilde öğretmen öğrenci ilişkisinde katılımcıların ifadelerinde sınıfta otorite kurmada, öğretmenin yeterliliğinin başat rol oynadığı, rol model olmanın ve sevgi temelli yaklaşımın öne çıktığı sonucuna ulaşılmıştır.

Çalışma kapsamında katılımcıların "Öğretmen de öğrenci de sınırları aşmamalı" alt temasında sınıf içi gündelik deneyimlerinde, öğretmen-öğrenci arasındaki mesafe ile ilgili birbirinden farklı deneyimler yaşadıkları söylenebilir. Söz konusu süreçte, öğretmenlerin öğrencilere rol model olarak davranışlarını düzenlemelerine fırsat verdikleri, örneğin kullandıkları dil ile öğrencilerin de konuşma tarzlarında belirleyici etkiye sahip oldukları söylenebilir. Öğretmenler davranışlarıyla öğrenciye örnek olmaktadırlar (Tofur, 2019). Öğretmen öğrenci arasında olması gereken mesafenin boyutunda da öğretmenin öğrencisine örnek olabileceği söylenebilir. İnsan ilişkilerinde belirleyici bir role sahip olan kararlılık ve tutarlılık ilkesi, öğretmenin her öğrenciye eşit mesafede durmasını sağlamaktadır (Demirbolat, 2018). Çalışmada yer alan katılımcı görüşlerinden olan öğretmenin kararlılık ve tutarlılık ilkeleri çerçevesinde hareket etmesi Demirbolat'ın (2018) bulgularıyla örtüşmektedir. Diğer yandan başarılı öğretmenlerin sıcak, kibar, arkadaş canlısı, demokratik ve işbirlikçi, tutarlı ve açık fikirli kişiler olduğu düşünüldüğünde, çalışmada değinilen, öğretmenin öğrencilerle kurmaya çalıştıkları mesafede öğrencilerin uyması gereken kuralları açıkça belirtmeleri önemlidir.

Çalışma kapsamında elde edilen bulgular doğrultusunda "Öğretmenin müdahalesi var ama sınırlı" alt 
teması sınıf içi gündelik deneyimlerde öğrencilerin sergiledikleri istenmeyen davranışların yönetilmesi süreciyle ilgilidir. Katılımcılar gürültü, bağırma, öğrencilerin ve öğretmenin dikkatini dağıtma gibi davranışları istenmeyen davranış olarak nitelendirmişlerdir. Öztürk (2019) ve Şahin (2005) çalışmalarında tehdit, bağırma, sınıf içinde gürültü yapma, kurallara uymama, öğrencilerin ve öğretmenlerin dikkatini dağıtma, öğretmene karşı üstün olduklarını ispatlamak için çatışma halinde olma, umursamaz tavırlar gibi davranışların sınıf içinde istenmeyen davranışlar olarak saptamışlardır. Katılımcılar sınıfta meydana gelen istenmeyen davranışların eğitim-öğretimin amacına ulaşmasını sekteye uğrattığını belirterek bu davranışları sergileyen öğrencilere müdahalenin kaçınılmaz olduğunu ifade etmişlerdir. Burada ayrıca öğretmenin müdahalesinin sınırlı olduğuna da vurgu yapmışlardır. Alan yazında çalışmada elde edilen bulgularla paralellik gösteren araştırmalara rastlanmıştır. Sınıfta öğrenciler her zaman istendik yönde davranış ortaya koymamakta, söz konusu istenmeyen davranışların yönetimi ise öğretmenin etkili bir eğitim öğretim ortamının oluşturulması için yapması gereken görevleri arasında yer almaktadır (Koçak, 2019). İstenmeyen davranış, sınıf düzenini bozan, eğitim öğretim etkinliklerinin amacına ulaşmasını ve verimli zaman kullanımını engelleyen davranışlardır (Başar, 2011). İstenmeyen davranışlar sınıfta oluşturduğu olumsuz hava nedeniyle hem sınıf içi iletişimi bozmakta hem de öğrenci ve öğretmenlerin psikolojik ve fizyolojik gerilimine sebep olmaktadır (Gökyer \& Doğan, 2016). Katılımcılar istenmeyen davranışlara müdahale ederken öğrencilerin gelişim dönemlerini dikkate aldıklarını belirtmektedirler. Öğrencinin istenmeyen davranışlarında artış meydana gelmesi içinde bulunduğu gelişim dönemleriyle de yakından ilgilidir. Örneğin, ergenlik döneminde kendini karşı cinse kabul ettirme ve popülerlik kazanma isteğinin artması dikkat çekme ve olumsuz davranış sergileyen popüler gruplara uyma davranışı sergileyebilmektedirler (Öztürk, 2019). İstenmeyen davranışları önlemek için kullanılan dil ve eylemler, öğrencilerin sosyal ve duygusal gelişimleri açısından da önemlidir (Bozkurt 2018). Bu konuda katılımcılar, belirtilen gelişim dönemindeki durumların farkında olduklarını ve öğrencinin kişiliğini zedelemeyecek çeşitli müdahalelerde bulunduklarını belirtmişlerdir. Bunun yanı sıra katılımcıların olumsuz davranışa müdahalelerinde sözlü olmayan mesajları da sık sık kullandıkları saptanmıştır. İstenmeyen davranışları önleme sürecinde sözlü olmayan mesajların kritik öneme sahip olduğu yapılan bazı çalışmalarda belirlenmiştir (Balıkçı, 2019; Koçak, 2019).

Çalışma kapsamında araştırmacılara aşağıdaki öneriler sunulmuştur.

1. Bu araştırmanın çalışma grubu sadece öğretmenlerden oluşmuştur. Farklı araştırmalarda çalışma grubunda öğrencilere de yer verilerek sınıf içi gündelik deneyimler, sınıfın bir başka unsuru olan öğrencilerin bakış açısıyla incelenebilir.

2. Araştırma Millı̂ Eğitim Bakanlığına bağlı kamu okullarında görev yapan öğretmenlerle yürütülmüştür. Özel okullarda görev yapan öğretmenlerle de benzer araştırmalar yürütülebilir.

\section{Yazarların Beyanı}

Araştırmacıların katkı oranı beyanı: Verilerin toplanması, analiz edilmesi ve makalenin yazım aşamasında bütün araştırmacılar birlikte çalışmıştır.

Etik Kurul Kararı: Karamanoğlu Mehmetbey Üniversitesi, Bilimsel Araştırma ve Yayın Etik Kurulu 17.08.2021 tarihli 26294 sayll kararl.

Çatışma beyanı: Araştırma sürecinde herhangi bir kişi ya da kurumla çıkar çatışması yaşanmamıştır.

Destek ve teşekkür: Bu çalışmaya desteğini sunan katılımcılara teşekkürlerimizi sunarız.

\section{Kaynaklar}

Aksoy, N. (1999). Classroom management and student discipline in elementary schools of Ankara (Turkey). [Yayımlanmamış Doktora Tezi]. University of Cincinnati.

Arslan, M. (2013). Illköğretim okulu öğretmenlerinin öğretmenlik mesleğine girmelerindeki güdüleri. [Yayımlanmamış Yüksek Lisans Tezi]. Orta Doğu Teknik Üniversitesi. 
Balıkçı, A. (2019). Sınıfta istenmeyen davranışlar ve çözüm önerileri. Elife Doğan Kılıç (Ed.), Sınıf Yönetimi içinde (ss. 83-100). Murat.

Başar, H. (2011). Sinıf yönetimi. Anı.

Blass, K. (2018). Examine the relationship between effective classroom communication and student behavior and classroom efficiency or loss of instruction time. Education: Student Scholarship \& Creative Works. 7. https://jayscholar.etown.edu/edstu/7

Bozkurt, S. (2018). Sınıf düzeni ve disiplini. Ayşe Ottekin Demirbolat (Ed.), Sımıf Yönetimi içinde (ss. 179-225). Pegem A.

Celep, C. (2002). Sinıf yönetimi ve disiplini. Anı.

Conroy, M.A., Sutherland, K.S., Al-Hendawi, M., \& Vo, A. (2009). Creating a positive classroom atmosphere: Teacher's use of effective praise and feedback. Beyond Behavior,18(2), 18-26.

Creswell, J. W. (2002). Research design: Qualitative, quantitative. and mixed methods approaches. Second edition. SAGE Publications, International Educational and Professional Publisher. Thousand Oaks London, New Delhi.

Çakmak, M. (2009). Öğrenmeye uygun olumlu bir sınıf ortamı oluşturmada öğretmen davranışları: Örnekler ve öneriler. L. Küçükahmet (Eds.), Sınıf Yönetimi içinde (ss. 295-328). Pegem A.

Çelik, V. (2009). Sinıf yönetimi. 5. Baskı. Nobel.

Dance, F. E. X. (1970). The "concept" of communication. Journal of Communication, 20(2), 201-210.

Demirbolat, A. O. (2018). Sınıfın doğasını anlamak. Ayşe Ottekin Demirbolat (Ed.), Sınıf Yönetimi içinde (ss. 134). Pegem A.

Denzin, N. K., \& Lincoln, Y. S. (1994). Introduction: Entering the field of qualitative research. In N. K. Denzin \& Y. S. Lincoln. (Eds.). Handbook of qualitative research. Thousand Oaks. Sage.

Djigic, G. \& Stojiljkovic, S. (2011). Classroom management styles, classroom climate and school achievement. Procedia-Social and Behavioral Science 29(1), 819-828.

Ekici, G. (2008). Sınıf yönetimi dersinin öğretmen adaylarının sınıf yönetimine yönelik tutum ve inanç kazanma düzeyine etkisi. Ç.Ü. Sosyal Bilimler Enstitüsü Dergisi, 17(3), 167-182.

Erdoğan, İ. (2011). Sinıf yönetimi. Alfa.

Ergen, Y. (2018). Bir eğitim ve öğrenme ortamı olarak sınıf. K. Kıroğlu ve C. Elma (Ed.), Eğitime Giriş içinde (ss.314-331). Pegem A.

Fumoto, H., Hargreaves, D. J. \& Maxwell, S. (2004). The concept of teaching: a reappraisal. Early Years 24(2), 179-191.

Gablinske, P. B. (2014). A case study of student and teacher relationships and the effect on student learning. [Unpublished Doctorate Thesis]. University of Rhode Island.

Gareth, T. (2014). Effective classroom management: The Essentials. New York: Teachers Colege Press, Columbia University.

Gonder, P. O. \& Hymes, D. (1994). Improving school climate and culture. Arlington: American Association of School Administrators.

Gordon, T. (2008). Etkili öğretmenlik eğitimi. 1.Baskı. Profil.

Gökyer, N. \& Doğan, B. (2016). İstenmeyen öğrenci davranışları ve nedenlerine ilişkin yönetici ve öğretmen görüşleri. Fırat Üniversitesi Sosyal Bilimler Dergisi, 26(1), 93-105.

Güçlü, N. (2000). Öğretmen davranışları. Milli Ĕ̆itim Dergisi, 147, 21-23. 
Hallinan, M.T. (2008). Teacher influences on students' attachment to school. Sociology of Education, 81(3), 271283.

Hamre, B.K., Pianta, R.C., Burchinal, M., Field, S, Crouch, J.L., Downer, J. T., Howes, C., LaParo, K., \& Little, C.S. (2012). A course on effective teacher-child interactions: Effects on teacher beliefs, knowledge, and observed practice. American Educational Research Journal, 49 (1), 88-123.

Harris, D. N., \& Sass, T. R. (2011). Teacher training, teacher quality and student achievement. Journal of public economics, 95(7-8), 798-812.

Horney, K. (1991). Neurosis and human growth: The struggle towrads self realization. W. W. Norton \& Company. İhtiyaroğlu, N. (2018). İletişim ve etkileşim. A. Ottekin Demirbolat (Eds.), Sınıf Yönetimi içinde. Pegem A.

Jenkins, K., Smith, H., \& Maxwell, T. (2009). Challenging experiences faced by beginning casual teachers: Here one day and gone the next!. Asia-Pacific Journal of Teacher Education, 37(1), 63-78.

Kocatürk, H. E. (2019). Sınıf yönetiminin temelleri ve modelleri. E. Doğan Kılıç (Ed.), Sınıf Yönetimi içinde. (ss. 17-26). Murat.

Koçak, S. (2019). Sınıfta istenmeyen davranışlar ve çözüm önerileri. E. Doğan Kılıç (Eds.), Sınıf Yönetimi içinde. (ss. 125-145). Murat.

Lincoln, Y.S. \& Guba, E.G. (1985). Naturalistic inquiry. Sage.

Lindqvist, H., Weurlander, M., Wernerson, A., \& Thornberg, R. (2017). Resolving feelings of professional inadequacy: Student teachers' coping with distressful situations. Teaching and Teacher Education, 64, 270279.

Martin, N. \& Baldwin, B.(1993a). An examination of the construct validity of the inventory of classroom management style. Paper presented at the Annual Conference of the Mid-South Educational Research Association, New Orleans, LA.

Martin, N. \& Baldwin, B.(1993b). Validation of an inventory of classroom management style: Differences between novice and experienced teachers. [Paper presentation]. Atlanta, GA.

Marzano, R. J. (2003). What works in schools: Translating research into action. ASCD.

Miles, M. B. and Huberman, A. M. (1994). Qualitative data analysis: An expanded sourcebook. Thousand Oaks. Sage.

Milli Eğitim Temel Kanunu (1973), Resmi. Gazete (Sayı: 14574), https://www.mevzuat.gov.tr/MevzuatMetin/1.5.1739 Erişim Tarihi: 03.05.2021

Morgan, S. R. (1977). Personality variables as predictors of empathy. Behavioral Disorders,2(2), 89-94.

Nurmi, J. E. (2012). Students'characteristics and teacher-child relationships in instruction: A metaanalysis. Educational Research Review, 7(3), 177-197.

Öztürk, B. (2019). İstenmeyen davranışların önlenmesi ve giderilmesi. E. Karip (Eds.), Sınıf Yönetimi içinde. (ss. 149-192). Pegem.

Patton, M. (1990). Qualitative evaluation and research methods. Sage.

Salar, R. \& Turgut, Ü. (2019). Farklılaştııılmış öğretimin sınıf iklimine etkisi: Nitel bir çalışma. Cumhuriyet Uluslararası Ĕ̆itim Dergisi, 8(4), 1048-1068.

Schmuck, R. and Schmuck, P. (1978). Group processes in the classroom. https://eric.ed.gov/?id=ED137166

Şahin, O. (2005). Illköğretim okulları 1. kademe 5. sını öğrencilerinin gösterdikleri istenmeyen davranışların görülme derecesi ve bu davranışlara ilişkin öğretmenlerin kullandikları çözüm stratejileri (Bolu ili örneği). [Yayımlanmış Yüksek Lisans Tezi]. Abant İzzet Baysal Üniversitesi. 
Tofur, S. (2019). Sınıfın yönetiminde iletişim. E. Doğan Kılıç (Eds.), Sınıf Yönetimi içinde. (ss. 49-61). Murat.

Turan, S. (2020). Sınıf yönetiminin temelleri. M. Şişman ve S. Turan (Eds.), Sınıf Yönetimi içinde. (ss. 1-20). Pegem.

Wragg, E. C. \& Dooley, P. A. (1996). Class management during teaching practice. E. C. Wragg (Eds.), Classroom Teaching Skills içinde (ss. 21-46). Routledge.

Yılmaz, E. (2017). Bir meslek olarak öğretmenlik. E. Karip (Eds.), Eğitim Bilimine Giriş içinde. (ss. 365-384). Pegem A.

Yılmaz, K. \& Tosun, M. F. (2013). Öğretmenlerin eğitim inançları ile öğretmen öğrenci ilişkilerine yönelik görüşleri arasındaki ilişki. Ĕ̆itim ve Öğretim Araştırmaları Dergisi, 2(4), 205-218.

Yin, R. K. (2003). Applications of case study research (2nd ed.). Sage, Thousand Oaks.

Yüksel, A. H., (2019). İletişim kavram ve tanımı. Uğur Demiray (Ed.), Etkili İletişim içinde. (ss. 2-42) Pegem. 


\section{EXTENDED ABSTRACT}

\section{Introduction}

Prior studies have tended to focus on issues such as school management, teachers' organisational behaviours and teachers' leadership skills, which all develop outside of the classroom and have only an indirect effect on experiences within the classroom. Such studies have generally applied quantitative methods and results-oriented designs. As the main purpose of schooling is to provide in-class learning, the present researchers have chosen to focus on the in-class experiences of students and teachers, which allows for the exploration of the most intense interactions between the groups in their most appropriate setting. From this perspective, it is important to examine the daily experiences of teachers in their classrooms as well as to determine how they make sense of those experiences. In light of this, the main purpose of this study is to examine the daily experiences of teachers in the classroom and reveal how they make sense of those experiences using a phenomenological approach. To accomplish these research aims, teachers' daily classroom experiences in terms of their communication and interaction with students, their classroom management processes and the learning environment are examined.

\section{Method}

In the present study, a phenomenological design involving a qualitative research approach is used to examine teachers' daily classroom experiences and elucidate how they make sense of those experiences. The participants comprise five teachers who work in public schools affiliated with the Ministry of National Education. The participants are recruited by means of the purposive and typical sampling method. The data required for the study are obtained through semi-structured interviews with the participants. The interview form is prepared in line with information obtained via a review of the prior literature, and the form is finalised following criticism and suggestions by experts in the field. The content analysis technique is used to analyse the collected data. First, the raw data are read by the researcher, common points are identified in the answers provided and separate codes are created. Next, based on the codes, certain main and sub-themes are developed and the data are presented in a descriptive manner. The NVivo 12 qualitative data analysis program is used throughout this process.

\section{Results}

The analysis of the interview data reveals that positive communication in the classroom is a basic element that plays a central role in the daily experiences of teachers. In this context, the participating teachers stated that developing an appropriate, healthy and positive communication style when engaging with students is necessary to foster a positive classroom climate and ensure that the classroom learning is of a more permanent nature. It is important for teachers to have authority if classroom learning is to take place as intended. When the participants' statements are examined, it can be seen that their experiences of exercising authority differ, with some participants assigning greater importance to the cognitive dimension of the teaching profession, while others assign more importance to the affective and behavioural dimensions. Yet, all of the teachers attempt to exercise in-class authority through practices that fall within the framework of these dimensions. Moreover, the principles of determination and consistency, which both play a decisive role in human relations, are also important when it comes to teacher-student relations in the classroom, where communication between the two groups is the most intense.

The participants all emphasised the importance of a determined attitude on the part of teachers in order to ensure that the boundaries associated with teacher-student relations are not violated. Of course, undesirable student behaviours can always occur in the classroom, and when such behaviours become too much, they can negatively affect the learning environment. However, the limited sanctions available for teachers to impose in response to undesirable behaviours and the lack of support provided by some parents render the possible interventions in this regard rather limited. In this context, the participants stated that effective communication skills, tone of voice, gestures that mimic acceptable behaviours and acting as a role model all play important roles in the process of managing students' undesirable behaviours. 


\section{Conclusion}

When the participating teachers' views of their daily classroom experiences are evaluated, four sub-themes emerge, namely 'It is important to catch the frequency', 'Ways to establish authority in the classroom', 'Both the teacher and the student should not exceed the limits' and 'There is a teacher's intervention, but it is limited'. In terms of the 'It is important to catch the frequency' sub-theme, the participants saw communication as being central to their relationships with students during their daily experiences in the classroom. Yet, with regard to the 'Ways to provide authority in the classroom' sub-theme, the participants reported shaping their own behaviours and fostering the classroom atmosphere by considering the different dimensions of the teaching profession in relation to both their daily classroom experiences and their relations with students. For the 'Both the teacher and the student should not exceed the limits' sub-theme, the participants discussed different experiences concerning the distance between the teacher and the student. In accordance with the other findings of the study, the 'There is a teacher's intervention, but it is limited' sub-theme is related to the process of managing undesirable behaviours exhibited by students. The participants described behaviours such as noise, shouting and distraction on the part of both teachers and students as being undesirable behaviours. 